\title{
Resistance to freezing in three Eucalyptus globulus Labill subspecies
}

\author{
Priscila Moraga S. \\ Facultad de Ciencias Forestales \\ Universidad de Concepción \\ Barrio Universitario s/n, Concepción, Chile \\ Tel: 05641204006 \\ Fax: 05641247517 \\ E-mail: prmoraga@udec.cl \\ René Escobar* \\ Facultad de Ciencias Forestales \\ Universidad de Concepción \\ Barrio Universitario s/n, Concepción, Chile \\ Tel: 05641204006 \\ Fax: 05641247517 \\ E-mail: rescobar@udec.cl \\ Sofía Valenzuela A. \\ Centro de Biotecnología y \\ Facultad de Ciencias Forestales \\ Universidad de Concepción \\ Barrio Universitario s/n, Concepción, Chile \\ Tel: 05641204697 \\ Fax: 05641247517 \\ E-mail: sofvalen@udec.cl
}

Financial support: Grant INNOVA Bio-Bio 03-B1-210-L1.

Keywords: cold resistance, ssp bicostata, ssp globulus, ssp maidenii.

The resistance to low temperatures was assessed in seedlings of three subspecies of E. globulus (ssp globulus, ssp bicostata and ssp maidenii) of two different provenances. Lethal temperature $50 \quad\left(\mathbf{L T}_{50}\right)$ was obtained by measuring the electrolytic conductivity, nucleation and freezing temperatures were obtained by thermal analysis and the total soluble carbohydrates concentration was determined through the phenolsulphuric method. Results showed that the most resistant provenance corresponded to Bolaro Mountain of ssp maidenii with a $\mathbf{L T}_{50}$ lower than $-9^{\circ} \mathrm{C}$. The provenance Moogora of ssp globulus, had a $\mathbf{L T}_{50}$ of $8.47^{\circ} \mathrm{C}$, which situates it, as the second most resistant to low temperatures. According to the nucleation and freezing temperatures, the results indicate that all the provenances analyzed evaded the formation of ice, except for Bolaro Mountain of ssp maidenii which was tolerant to freezing. Finally, an inverse correlation $(r=$ 0.89) between the content of total soluble carbohydrates and the $\mathbf{L T}_{50}$ was found, indicating the cryoprotection effect of these in the resistance to low temperatures.

Eucalyptus globulus Labill ssp globulus is the second most important specie in forest plantations of Chile, after Pinus radiata D. DON, due to its fast growth and fiber quality (Doughty, 2000; Infor, 2004). However, there are some restrictions for its establishment, due to the freezing sensitivity of the young plantations (Skolmen et al. 1990), limiting the lands where it can be cultivated within Chile (Infor, 2004). The survival of this specie during a frost strongly depends on both its constitutive tolerance and acclimatation capacity.

Cold, salt or drought stresses are some of the main environmental factors that strongly affect growth, productivity and plant development (Alberdi and Corcuera, 1991; Nilsen and Orcutt, 1996). According to Larcher (1995) low temperatures can be the direct cause of damages to plant cells, causing a type of water-deficit stress (Griffith and Antikainen, 1996). The resistance or sensitivity to the stress depends on the species, the genotype, and the development age of the plant (Palva et al. 2002).

The resistance to freezing can be defined as the lowest temperature, under the freezing point to which a plant can be exposed without being damaged (Duryea and McClain, 1984). It is frequently defined as the minimum temperature at which half of the seedlings are damaged, and is expressed as lethal temperature 50 or $\mathrm{LT}_{50}$ (Glerum, 1985;

\footnotetext{
* Corresponding author
} 
Larcher, 1995).

The resistance to frost in seedlings is given by mechanisms of evasion and tolerance (Larcher, 1995; Nilsen and Orcutt, 1996). The first corresponds to a mechanism in which seedlings avoid direct contact of its tissues with freezing temperatures, which means, they avoid the formation on ice in its tissues.

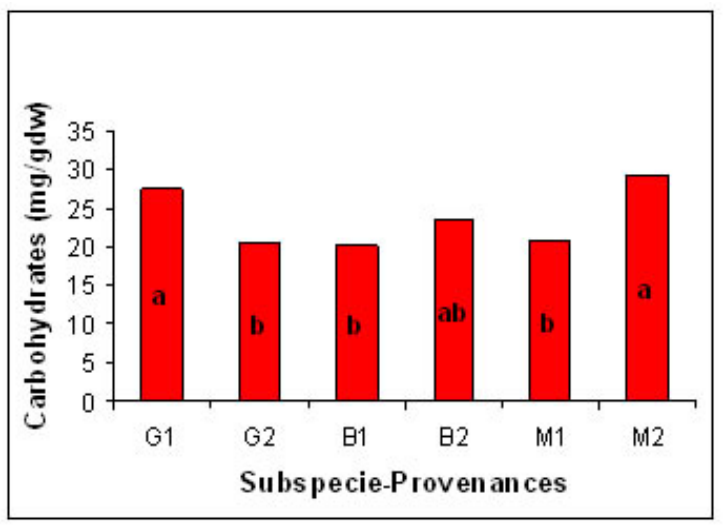

Figure 1. Average values of total soluble carbohydrates.

The tolerance mechanism includes the process that allows the icing in plant tissues without lethal consequences, making this mechanism act constitutively or induced (Larcher, 1995; Nilsen and Orcutt, 1996). Enhancement of freezing tolerance is also accompanied by accumulation of compatible solutes such as soluble sugars and amino acids (Palonen and Junttila, 1999). These solutes are believed to protect cellular membranes and enzymes from irreversible damage caused by freezing.

Therefore, the information that the nursery owner handles is important, specially regarding the external factors that influence or are involved in cold-resistance, as well as the internal physiological and biochemical changes that are associated to low temperature resistance in plants. This is basically related to the freezing produced at intra and intercellular level and the resulting injury (Glerum, 1985). In Chile, attending to the demands of the pulp industries, numerous alternatives have been investigated to overcome the freezing sensibility of E. globulus. Among these are identification of cold hardening genotypes of E. globulus, or the plantation of alternative species which are more cold resistant. However, a possible alternative that has not been studied, it is the assessment of frost tolerance and the mechanisms involved in different subspecies of $E$. globulus. The subspecies bicostata and maidenii are of special interest, since they have been described by some authors as more resistant to frosts (Skolmen et al. 1990), and have a similar pulp yield to the subspecies globulus (Resquin, 2003).

The aim of this work is to assess the resistance to freezing and understand the mechanism used by plantlets of the subspecies bicostata, globulus and maidenii, of two different seed provenances from Australia. In addition, the total soluble carbohydrate concentration in plantlets was analyzed.

\section{MATERIALS AND METHODS}

\section{Materials}

Three of the four existing subspecies of E. globulus were used in this study. Each subspecies analyzed was obtained from seeds from two provenances of Australia (Table 1), which gave origin to plants produced in root covered and open sky conditions. Material tested was 9 months of age. Previous to the test, plantlets were hardened by a process that consisted of apical and lateral pruning, in addition to water stress (irrigation each 4 days, $40 \%$ container capacity).

\section{Determination of freezing resistance}

$\mathrm{LT}_{50}$ was determined by electrolytic conductivity, as described (Raymond et al. 1986). Leaf discs of $8 \mathrm{~mm}$ diameter were transferred to a cold air chamber and analyzed at temperatures of $-3,-4.5,-6,-7.5$ and $-9^{\circ} \mathrm{C}$. The electrolytic conductivity was recorded, and by interpolation the $\mathrm{LT}_{50}$ was obtained. The nucleation and freezing temperatures were determined by thermal analysis slightly modified from the one described by Quamme (1991).

\section{Determination of the total soluble sugars}

Carbohydrate concentration was determined through the phenol sulphuric method, for which leaf samples $(0.3 \mathrm{~g})$ were used. The absorbance was measured with a spectrophotometer at $485 \mathrm{~nm}$. In order to obtain the values of the sugar concentrations a calibration curve was used.

Table 1. Background of the subspecies of Eucalyptus globulus Labill.

\begin{tabular}{|l|l|l|l|l|}
\hline Subspecies & CSIRO code & Assay code & Provenance & State \\
\hline globulus & 16470 & G1 & Moogora & Tasmania \\
\hline globulus & 16417 & G2 & N Cape Banan Island & Tasmania \\
\hline bicostata & 16370 & B1 & M T Strathbogie & Victoria \\
\hline bicostata & 17965 & B2 & Tumbarumba & N.S. Wales \\
\hline maidenii & 17745 & M1 & Yurammie SF & N.S. Wales \\
\hline maidenii & 17769 & M2 & Bolaro Mountain & N.S. Wales \\
\hline
\end{tabular}




\section{Design and statistical analysis}

The experimental design used was random simple for resistance to freezing and total soluble sugars, but in resistance to freezing was determinated with bifactorial model (temperature and provenance) and 8 seedlings by treatment. For the analysis of the results a test of significance for the comparison of the averages of the treatments through the test of Tukey was made $(\alpha=0.005)$.

\section{RESULTS AND DISCUSSION}

The freezing resistance varied in a range between $-7.1^{\circ} \mathrm{C}$, for the less resistant plants up to less than $-9^{\circ} \mathrm{C}$, for the most resistant ones. In Table 2, the values of $\mathrm{LT}_{50}$, nucleation and freezing temperatures are shown.

The provenance Bolaro Mountain of ssp maidenii with a $\mathrm{LT}_{50}$ below $-9^{\circ} \mathrm{C}$ was the most resistant sub-specie to freezing in this study. The Moogora provenance of $s s p$ globulus, had a $\mathrm{LT}_{50}$ of $-8.5^{\circ} \mathrm{C}$, was classified as the second most resistant sub-specie to freezing, and with a resistance level greater than the one commonly mentioned in the literature.

In Figure 1, the differences in the total carbohydrate concentration is shown, for the different subspecies from different provenances (intraspecific variation), being significant for the subspecies globulus and maidenii.

Also, an inverse correlation between the total soluble carbohydrate content and the $\mathrm{LT}_{50}(\mathrm{r}=-0.89)$ was found. The same is mentioned by Johnson and Cline (1991).

An approach being used in several countries is to study eucalypts hybrids for use in plantation forestry to incorporate frost tolerance into marketable species. Scott et al. (2002) made five large field trials at four altitudes in Tasmania, southern Australia to measure performance of $E$. gunnii, E. globulus, their hybrids and E. nitens, the species currently used at higher altitudes. Their results showed that E. gunnii x E. globulus $\mathrm{F} 1$ hybrids did not grow as rapidly as $E$. nitens and were more damaged by possums. This means that $E$. nitens should generally remain the species of choice for forestry at high altitudes in southern Australia.

In our study, three different sub-species of E. globulus, from two provenances were assessed. Hardened seedlings of all subspecies should have a higher resistance to low temperatures than in natural conditions. This would indicate that the process of hardening in nursery can induce a resistance equal or superior to the naturally more resistant species.

By the results obtained in $\mathrm{LT}_{50}$, the process of plantation in zones with incidence of low temperatures (up to $-7^{\circ} \mathrm{C}$ ), should not to be a problem for plants properly hardened of any of the analyzed provenances, especially for Moogora and Bolaro Mountain. According to the nucleation and freezing temperatures, the results indicate that all the analyzed provenances evade the formation of ice in their leaves, suggesting that supercooling is the most probable mechanism conferring resistance to these plants. This is not observed in the provenance Bolaro Mountain of ssp maidenii which did tolerate freezing.

Almeida et al. (1995) tested some provenance trials of $E$. globulus in Portugal and observed that the effect of provenance is significant, especially on the sites with more unfavourable conditions and their results showed that ssp bicostata and ssp maidenii had a higher frost tolerance overall, and within the ssp globulus, provenances from regions where the subspecies is an exotic are more frost tolerant than the Australian provenances. These results agree with those found in our study, since there were differences within two provenances tested of each subspecies. For example, in the ssp maidenii, a provenance was more resistant to low temperatures, whilst the other had one of the lowest value of $\mathrm{LT}_{50}$.

According to the results obtained for total soluble carbohydrate content, it is a good indicator of the resistance to low temperatures. If these results were correlated with the $\mathrm{LT}_{50}$, an inverse relationship for all the provenances can be observed, indicating that as the level of soluble carbohydrates increases in the cell, they are able to resist lower temperatures, supporting the theory that soluble sugars function as cryoprotectants in plant tissues, especially at membrane level. This agrees with the results of Tinus et al. (2000) that found a near relationship between cold hardiness and the absolute concentration of soluble sugars.

Similar results were found, when treating callus cultures of wheat genotypes differing in frost tolerance (Kerepesi et al. 2004). On the other hand, Zuther et al. (2004) observed that

Table 2. Values of $\mathrm{LT}_{50}$, nucleation and freezing temperatures.

\begin{tabular}{|c|c|c|c|}
\hline Lot ssp & $\begin{array}{c}\mathbf{L T}_{\mathbf{5 0}} \\
\left.\mathbf{(}{ }^{\circ} \mathbf{C}\right)\end{array}$ & $\begin{array}{c}\text { Nucleation temperature } \\
\left({ }^{\circ} \mathbf{C}\right)\end{array}$ & $\begin{array}{c}\text { Freezing temperature } \\
\left({ }^{\circ} \mathbf{C}\right)\end{array}$ \\
\hline G1 (globulus) & -8.47 & $-8.76 \pm 0.29$ & $-5.46 \pm 0.22$ \\
\hline G2 (globulus) & -7.68 & $-8.08 \pm 0.29$ & $-5.61 \pm 0.18$ \\
\hline B1 (bicostata) & $-7,10$ & $-8.03 \pm 0.20$ & $-5.34 \pm 0.44$ \\
\hline B2 (bicostata) & -8.01 & $-8.37 \pm 0.40$ & $-5.02 \pm 0.17$ \\
\hline M1 (maidenii) & -7.10 & $-7.16 \pm 0.35$ & $-4.35 \pm 0.49$ \\
\hline M2 (maidenii) & $<-9$ & $-3.77 \pm 0.33$ & $-1.78 \pm 0.29$ \\
\hline
\end{tabular}


raffinose did not have a direct effect on basic freezing tolerance or cold acclimatation when using either transgenic lines or mutants of Arabidopsis. Dalmannsdottir et al. (2001), studied white clover in relation to frost tolerance, using different cultivars. They found that sucrose was the most abundant water-soluble carbohydrate, but during the month of September (spring) populations had similar levels of this carbohydrate, which decreased in January (winter) in one cultivar, the most frost tolerant, concluding that the selected population was more frost and ice-encasement than the original population in autumn. The same is found by Travert et al. (1997); they used cellsuspension culture hardened by exposure to lower temperatures obtained from hybrid of Eucalyptus spp. During the cold exposure the resistant cells accumulated soluble sugars, in particular fructose and sucrose, with a limited increase in cell osmolality. In contrast, the cell suspension that was unable to acclimate did not accumulate soluble sugars in response to the same cold treatment. Also Leborgne et al. (1995) made a comparison of soluble sugar content in various cell lines of $E$. gunnii exhibiting different freezing resistances revealed that the most resistant cell line contained the highest soluble sugar content.

\section{REFERENCES}

ALBERDI, Miriam and CORCUERA, Luis. Cold acclimation in plants. Phytochemistry, 1991, vol. 30, no. 10, p. 3177-3184.

ALMEIDA, M.; PEREIRA, H.; MIRANDA, I. and TOMÉ, M. Provenances trials of Eucalyptus globulus Labill. in Portugal. In: Sub-theme: Eucalypt breeding and genetics; Theme 4: Breeding and selection strategies; Eucalypt Plantations: Improving Fibre Yield abd Quality. Proceedings of CRCTHF-IUFRO Conference $\left(19^{\text {th }}-24^{\text {th }}\right.$ February 1995, Hobart, Australia). 1995.

DALMANNSDOTTIR, S.; HELGADOTTIR, A. and GUDLEIFSSON, B. Fatty acid and sugar content in white clover in relation to frost tolerance and oce-encasement tolerance. Annals of Botany, 2001, vol. 88, Supple. 1, p. 753-759

DOUGHTY, R. The Eucalyptus: A natural and commercial history of de Gum Tree. (Books reviews). Forest Science, 2000, vol. 46, no. 4, p. 585.

DURYEA, M. and McCLAIN, K. Altering seedling physiology to improve reforestation success. In: Proceedings of the Physiology Working Group Technical Session, Seedling Physiology and Reforestation Manual, Success I. $\left(16^{\text {th }}-20^{\text {th }}\right.$ October, 1983, Oregon, USA). Society of American Foresters National Convention Portland. DURYEA, M. and BROWN, G. eds., 1984. p. 77114.

GLERUM, C. Frost hardiness of coniferous seedlings: Principles and applications. Ministry of Natural Resources,
Maple, Ontario, Canada. 1985, p. 107-122.

GRIFFITH, M. and ANTIKAINEN, M. Extracellular ice formation in freezing-tolerant plants. Jai Press Incorporated. 1996, p. 107-139.

INFOR, 2004. (Instituto Forestal de Chile). Webs Proyectos INFOR. Proyecto FONDEF DOOI1036: "Captura de genotipos para el desarrollo de una raza de Eucalyptus globules tolerante al frío". Updated december 2004. [cited 30 junio 2005]. Available from Internet: http://www.infor.cl/webinfor/PW-CapturaEuca/index.htm.

JOHNSON, J. and CLINE, M. Seedlings quality of southern pines. In: DURYEA, M. and DOUGHERTY, P. eds. Forest Regeneration Manual. Dordrecht, Netherlands, 1991, p. 143-159.

KEREPESI, I.; BÁNYAI-STEFANOVITS, É. and GALIBA, G. Cold acclimation and abscisic acid induced alterations in carbohydrate content in calli of wheat genotypes differing in frost tolerance. Journal of Plant Physiology, 2004, vol. 161, no. 1, p. 131-133.

LARCHER, W. Physiological plant ecology. Plants under stress. Springer. Austria. 1995. 513 p. ISBN 3540435166.

LEBORGNE, N.; TEULIERES, C.; TRAVERT, S.; ROLS, M.P.; TEISSIE, J. and BOUDET, A.M. Introduction of specific carbohydrates into Eucalyptus gunnii cells increases their freezing tolerance. European Journal of Biochemistry, 1995, vol. 229, no. 3, p. 710-717.

NILSEN, E. and ORCUTT, D. The physiology of plants under stress. John Wiley \& Sons, Inc. United States of America. 1996, 704 p. ISBN 0471031526.

PALONEN, Pauliina and JUNTTILA, Olavi. Cold hardening of raspberry plants in vitro is enhanced by increasing sucrose in the culture medium. Physiologia Plantarum, 1999, vol. 106, no. 4, p. 386-392.

PALVA, E.T.; THTIHARJU, S.; TAMMINEN, I.; PUHAKAINEN, T.; LAITINEN, R.; SVENSSON, J.; HELENIUS, E. and HEINO, P. Biological mechanism of low temperature stress response: Cold acclimation and development of freezing tolerance in plants. Japan International Research Center for Agricultural Sciences, Working Report. 2002, p. 9-15.

PEREDO, M.; MORA, C. and CÁCERES, F. Wood properties and pulpwood quality of Eucalyptus globulus and Eucalyptus nitens in the south of Chile. In: Forest Products Society Annual meeting $\left(57,22^{\text {nd }}-25^{\text {th }}\right.$ June, 2003, Bellevue, WA, USA). Biographies and abstracts. 2003. p. 8. Available from Internet: http://www.forestprod.org/am03abs.pdf.

QUAMME, H.A. Application of thermal analysis to 
breeding fruit crops for increased cold hardiness. HortScience, 1991, vol. 26, no. 5, p. 513-517.

RAYMOND, C.A.; HARWOOD, C.E. and OWEN, J.V. A conductivity method for screening populations of eucalypts for frost damage and frost tolerance. Australian Journal of Botany, 1986, vol. 34, no. 4, p. 377-393.

RESQUÍN, F. Del árbol al papel. El país agropecuario [online]. 2 July 2003 [cited 30 June 2005]. Requires Adobe Acrobat Reader. Available from Internet: http://www.inia.org.uy/publicaciones/documentos/tb/ara/20 03/jul_03.pdf.

SCOTT, S.; McARTHUR, C.; POTTS, B. and KELSEY, J. Possum browsing- the downside to a eucalypt hybrid developed for frost tolerance in plantation forestry. Forest Ecology and Management, 2002, vol. 157, no. 1-3, p. 231245 .

SKOLMEN, R.G. and LEDIG, T.F. Eucalyptus globulus Labill. Bluegum eucalyptus. In: BURNS, R.; HONKALA, B. eds. Silvics of North America: 2. Hardwoods. Agric. handbook 654. Washington, DC: U.S. Department of Agriculture, Forest Service. 1990, p. 299-304.

TINUS, R.W.; BURR, K.E.; ATZMON, N. and RIOV, J. Relationship between carbohydrate concentration and root growth potential in coniferous seedlings from three climates during cold hardening and dehardening. Tree Physiology, 2000, vol. 20, no. 16, p. 1097-1104.

TRAVERT, S.; VALERIO, L.; FOURASTE, I.; BOUDET, A.M. and TEULIERES, C. Enrichment in specific soluble sugars of two eucalyptus cell-suspension cultures by various treatments enhances their frost tolerance via a noncolligative mechanism. Plant Physiology, 1997, vol. 114 , no. 4, p. 1433-1442.

ZUTHER, E.; BEUCHELA, K.; HUNDERTMARKA, M.; STITTA, M.; HINCHAA, D. and HEYERA, A.G. The role of raffinose in the cold acclimation response of Arabidopsis thaliana. FEBS Letters, 2004, vol. 576, no. 1, p. 169-173. 